University of Nebraska - Lincoln

DigitalCommons@University of Nebraska - Lincoln

Agronomy \& Horticulture -- Faculty Publications

Agronomy and Horticulture Department

3-1992

\title{
Registration of N27 Sweetclover Germplasm
}

\author{
Herman J. Gorz \\ United States Department of Agriculture \\ Francis A. Haskins \\ University of Nebraska-Lincoln, fhaskins@neb.rr.com \\ G. R. Manglitz \\ United States Department of Agrciulture \\ R. R. Smith \\ United States Department of Agrciulture \\ K. P. Vogel \\ United States Department of Agrciulture, kvogel1@unl.edu
}

Follow this and additional works at: https://digitalcommons.unl.edu/agronomyfacpub

Part of the Plant Sciences Commons

Gorz, Herman J.; Haskins, Francis A.; Manglitz, G. R.; Smith, R. R.; and Vogel, K. P., "Registration of N27 Sweetclover Germplasm" (1992). Agronomy \& Horticulture -- Faculty Publications. 241.

https://digitalcommons.unl.edu/agronomyfacpub/241

This Article is brought to you for free and open access by the Agronomy and Horticulture Department at DigitalCommons@University of Nebraska - Lincoln. It has been accepted for inclusion in Agronomy \& Horticulture -Faculty Publications by an authorized administrator of DigitalCommons@University of Nebraska - Lincoln. 


\section{REGISTRATION OF N27 SWEETCLOVER GERMPLASM}

N27 SWEETCLOVER [Melilotus officinalis (L.) Lam.] (Reg. no. GP-1, PI 552552) is a biennial, yellow-flowered, highcoumarin strain that was selected for large seed size and for resistance to the sweetclover aphid [Therioaphis riehmi (Börner)]. N27 was developed cooperatively by the USDAARS and the Nebraska Agricultural Research Division and was released in February 1991.

N27 was derived from a Turkish introduction, PI 178985. This introduction was unusual because it had much larger average seed size than most other introductions of $M$. officinalis. Initially, efforts to increase the seed size of P.I. 178985 involved selecting the largest seeds from field-harvested seed bulks followed by several cycles of mass selection for individual large-seeded plants with good agronomic traits. This seed-size selection was followed by three cycles of selection (2) for resistance to the sweetclover aphid, using selfed progeny of aphid-resistant plants identified in the previous generation as the source material in each cycle. In the third cycle of selection $89 \%$ of tested seedlings were resistant to the sweetclover aphid. Selfed seed from resistant plants identified in the third cycle of this selection was bulked and planted in a field isolated from other sweetclover to permit interpollination of the selected plants. All available seed was harvested in 1974, bulked, and held in cold storage until an isolated increase nursery was planted in 1989. N27 seed was harvested from this nursery in 1990. Seed weight of the released N27 was $3.2 \mathrm{mg} \mathrm{seed}^{-1}$. 'Madrid' sweetclover, by comparison, typically has a seed weight of about $2 \mathrm{mg}$ seed $^{-1}$.

Experiments have not been conducted in which the agronomic performance of N27 was compared directly with that of other sweetclover cultivars. However, studies with another PI 178985-based large-seeded strain, N13, have shown that increased seed size is associated with improved seedling emergence and early growth (1). Like N13, N27 is susceptible to blackstem disease (Cercospora davisii Ellis \& Everh.) and to attack by leafhoppers [Empoasca fabae (Harris)]. Nevertheless, the gains in seedling emergence and vigor that are associated with large seed size, and the aphid resistance of N27, should be useful in sweetclover improvement programs.

Seed of N27 will be distributed by the Department of Agronomy, University of Nebraska, Lincoln, NE 685830915. Germplasm amounts will be provided without cost to each applicant upon written request while supplies last. Recipients of seed are asked to make appropriate recognition of the source of the germplasm if it is used in the development of a new germplasm, parental line, or cultivar.

\section{H. J. Gorz, ${ }^{*}$ F. A. Haskins, G. R. Manglitz, R. R. SMith, AND K. P. VOGEl (3)}

\section{References and Notes}

1. Haskins, F.A., and H.J. Gorz. 1975. Influence of seed size, planting depth, and companion crop on emergence and vigor of seedlings in sweetclover. Agron. J. 67:652-654.

2. Manglitz, G.R., and H.J. Gorz. 1961. Resistance of sweetclover to the sweetclover aphid. J. Econ. Entomol. 54:1156-1160.

3. H.J. Gorz (retired) and K.P. Vogel, USDA-ARS and Dep. of Agronomy, F.A. Haskins (retired), Dep. of Agronomy, and G.R Manglitz (retired), USDA-ARS and Dep. of Entomology, University of Nebraska, Lincoln, NE 68583-0915; and R.R. Smith, USDA-ARS, U.S. Dairy Forage Res. Ctr. and Dep. of Agronomy, Univ. of Wisconsin, Madison, WI 53706. Cooperative investigations of the USDA-ARS and the Nebraska Agric. Res. Div. Published as Journal Series Paper no. 9570, Nebraska Agric. Res. Div. Registration by CSSA. Accepted 30 Sept. 1991. * Corresponding author.

Published in Crop Sci. 32:509 (1992). 